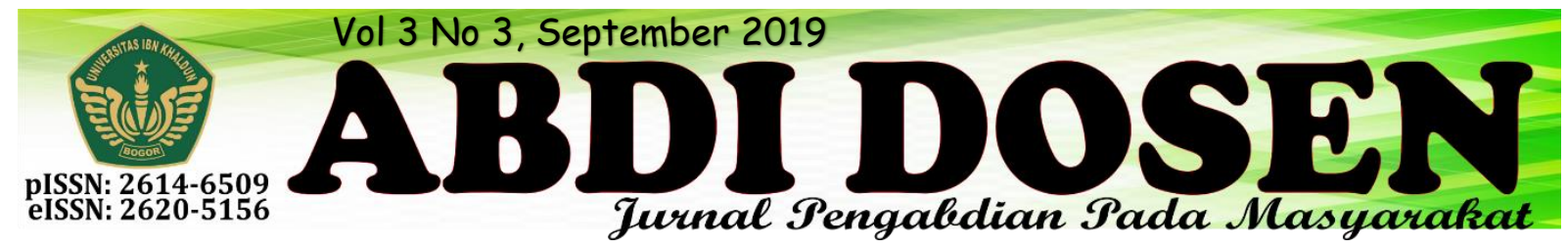

\title{
PEMBELAJARAN DAN PEMBERDAYAAN MASYARAKAT DI DESA CIHIDEUNG UDIK
}

\author{
Imas Kania Rahman ${ }^{1}$, Ricky Arrdiansyah ${ }^{2}$ \\ imas.kania@uika-bogor.ac.id \\ Fakultas Agama Islam Universitas Ibn Khaldun ${ }^{1}$, Mahasiswa KKN Kelompok 08 Tahun $2018^{2}$
}

\begin{abstract}
ABSTRAK
Sumber daya manusia merupakan aset utama dalam membangun suatu bangsa. Ketersediaan sumber daya alam (natural resources) yang melimpah dan adanya sumber daya modal serta teknologi yang semakin canggih, tidak akan mempunyai kontribusi yang bernilai tambah, tanpa didukung oleh adanya sumber daya manusia (human resources) yang berkualitas. Dengan demikian, peningkatan kualitas suatu bangsa sesungguhnya bertumpu pada peningkatan kualitas sumber manusianya, dan hanya akan dapat dicapai salah satunya melalui penekanan pada pentingnya pendidikan. Berangkat dari hal tersebut kami menganggap pentingnya pendidikan dan kesehatan dalam kehidupan. Salah satu tempatnya adalah di Desa Cihideung Udik Kecamatan Ciampea Kabupaten Bogor yang perlu mendapatkan perhatian khusus terkait dengan bidang pendidikan dan kesehatan. Hal ini dikarenakan kurangnya kesadaran masyarakat di daerah ini terhadap pentingnya pendidikan dan kesehatan, hal ini terlihat dari tidak tersedianya tempat pembuangan sampah dan anak-anak yang tidak masuk sekolah tanpa adanya alasan yang jelas, maka dari itu aspek pendidikan pun perlu mendapatkan perhatian agar masyarakat desa tersebut dapat belajar serta memahami dengan baik mengenai sistem pendidikan yang juga didukung dengan pemahaman akan pentingnya kesehatan bagi para warga di desa tersebut.
\end{abstract}

\section{Kata kunci : Pendidikan, Kesehatan, Lingkungan}

\section{PENDAHULUAN}

Kuliah Kerja Nyata (KKN) Tematik Terintegrasi Universitas Ibn Khaldun Bogor merupakan program implementasi salah satu rangkaian Tri Dharma perguruan tinggi yaitu pengabdian masyarakat. Program KKN diharapkan menjadi suatu pengalaman belajar yang baru untuk menambah pengetahuan, kemampuan, dan kesadaran hidup bermasyarakat. Penempatan mahasiswa di luar kampus diharapkan dapat dimanfaatkan untuk bisa bersosialisasi, membantu dan mendampingi masyarakat memanfaatkan potensi sumber daya alam lokal dan sumber daya manusia yang ada untuk mengatasi permasalahan masyarakat dalam kurun waktu tertentu. Disamping itu mahasiswa juga diharapkan mempu memberikan motivasi dan inovasi dalam segala bidang.

\section{Analisis Situasi}

Desa Cihideung Udik merupakan bagian dari kecamatan Ciampea, kabupaten Bogor, Propinsi Jawa barat. Desa Cihideung Udik terletak sekitar 10 kilometer dari pusat pemerintahan kecamatan. Di desa Ciampea. Pelaksanaan 
KKN UIKA kelompok 18 mengambil lokasi di Kp.Cihideung Pojok, yaitu RW 11 RT 08. Adapun gambaran umum dusun Kp. Cihideung Pojok sebagai lokasi KKN kelompok 18 adalah sebagai berikut:

\section{Letak geografis Desa Cihideung Udik}

Dusun terletak di bagian Barat desa Cihideung Udik dan berbatasan langsung dengan desa Situdaun.

\section{Keadaan alam dan potensi fisik}

Secara umum kondisi alam di kampungCihideung Pojok terdapat di dataran tinggi yang dikelilingi beberapa kebun. Mata pencaharian penduduk kebanyakan adalah bertani, buruh, berkebun, dan wirausaha. Lokasi KKN kami berdekatan dengan Desa Cihideung Udik yang mana jarak dapat ditepuh dengan kendaraan dengan waktu 30 menit.

\section{Keadaan perekonomian}

Sebagian besar penduduk bermata pencaharian sebagai pedagang dan buruh. Beberapa diantaranya juga bekerja sebagai buruh dan petani ikan lele dan gurame.

Organisasi kemasyarakatan di kampungCihideung Pojok RT 03 RW 12 sudah lama tidak berjalan baik dari ibu-ibu PKK, Karang taruna dan lain sebagainya. Beberapa hal yang selalu dilakukan warga untuk menjalin komunikasi dan silaturahmi adalah pengadaan pengajian tiap kamis sore di rumah ibu nyai, sabtu pagi untuk ibu-ibu di Mushola baitul Jannah dan malam senin untuk para pemuda, sedangkan untuk bapak-bapaknya sudah tidak berjalan. Kegiatan TPA pun berjalan sangat aktif di majelis ibu nyai. Dari segi pendidikan, tidak jauh dari lokasi $\mathrm{KKN}$ kami terdapat beberapa lembaga pendidikan baik negeri maupun swasta dari tingkat paud bahkan pondok pesantren. Kepadatan aktivitas transportasi selalu Nampak di pagi dan sore hari ketika para murid dari berbagai lembaga pendidikan mengawali dan mengakhiri kegiatan belajarnya di sekolah. Diantara lembaga pendidikan yang berlokasi di kampung Cihideung Pojok adalah SDN 03 , SMP dan SMA. Mayoritas penduduk di kampung Cihideung Udik beragama islam dan kegiatan keagamaan terpusat di mushola dan majlis taklim. Dan untuk kegiatan pengajian di malam hari dan pagi hari dilaksanakan bergiliran di Mushola.

\section{Keadaan Geografis}

Desa Cihideung udik merupakan salah satu desa di Kecamatan Ciampea Kabupaten Bogor, dengan luas wilayah 248ha dan jumlah penduduk sekitar 14.000 jiwa.

Batas wilayah Desa Cihideung udik adalah sebagai berikut :

Sebelah Utara : Kecamatan

Sebelah Barat $\quad \begin{array}{ll}\text { Rancabungur } \\ \text { : Kecamatan }\end{array}$

$\begin{array}{ll} & \text { Cibungbulang } \\ \text { Sebelah Selatan } & \text { : Kec. Tenjolaya, Kec. }\end{array}$ Pamijahan

Sebelah Timur : Kecamatan Dramag

\section{Kondisi Masyarakat}

Jumlah penduduk Desa Cihideung Udik sampai akhir5 Februari 2016 tercatat sebanyak 14.000 jiwa .

Keadaan mata pencaharian penduduk Desa Cihideung udik adalahPetani, penjahit dan mayoritas peternak ikan sebagai mata pencaharian utama mereka. Adapun tingkat pendidikan penduduk Desa Cihideung udik adalahSD, SLTP, SLTA, dan Lulusan perguruan tinggi.

\section{Kondisi Sosial}

Secara umum kondisi sosial keamanan dan kententraman di wilayah Desa Cihideung udik kampung cihideung pojok cukup aman dan terkendali. Dalam hal ini, kehidupan politik warga masyarakat dapat tersalurkan sesuai dengan aspirasinya. 


\section{METODOLOGI}

\section{Metodologi Penyelenggaraan KKN}

Langkah penyelenggaraan Kuliah Kerja Nyata (KKN) di Desa Cihideung Udik Kecamatan Ciampea dilakukan melalui beberapa tahapan, yaitu:

1. Pembagian Tugas Obsevasi

Sebelum melakukan pengamatan dan mencari data langsung dilapangan, dilakukan pembagian tugas observasi berdasarkan bidangnya masing-masing. Hal ini dilakukan mengingat program kerja yang akan dilaksanakan di Kampung Cihideung pojok Desa Cihideung Udik Kecamatan Ciampea harus sesuai dengan masalah dan kebutuhan yang ada di wilayah tersebut,sedangkan waktu yang telah ditentukan relative singkat. Oleh karena itulah untuk efisiense dan efektivitas waktu, dibuat empat kelompok observasi yang bertugas masing-masing melakukan observasi dan menunjuk koordinator bidang dari setiap bidang observasi tersebut.

2. Tahap Observasi

Pada tahap observasi ini diadakan pegamatan langsung di lapagan guna mengidentifikasi masalah yang ada di Kampung Cihideung pojok Desa Cihideung Udik Kecamatan Ciampea Tahapan ini berlangsung kurang lebih tujuh hari dimana dalam pelaksanaannya didukung langsung oleh aparat Desa dan warga sekitar.

3. Tahap Perumusan Masalah

Pada tahap ini informasi yang sudah didapatkan dari hasil observasi oleh masing-masing bidang dikumpulkan. Dan dalam pelaksanaannya diadakan musyawarah bersama dalam pemilihan masalah yang ditemukan disetiap bidang yang akan disusun kedalam program umum sesuai dengan bidangnya. Adapun hasil perumusan masalah di dapatkan dari Bidang Pendidikan, Sosial, Budaya dan Agama A. Bidang Pendidikan

1) Kurangnya pengetahuan agama bagi para pemuda dan anak-anak di Kampung Cihideung Pojok.

2) Masih minimnya fasilitas dan pengajar yang ada di lembaga pendidikan di kampung cihideung pojok.

B. Bidang Lingkungan

1) Kurangnya kesadaran masyarakat tentang kebersihan lingkungan

2) Tidak tersediannya bak sampah umum untuk menampung sampah rumah tangga.

3) Kurangnya kesadaran para pemuda dalam membersihkan lingkungan.

C. Bidang Ekonomi

1) Kurangnya kesadaran masyarakat untuk menabung

2) Belum adanya sosialisasi mengenai kewirausahaan kepada masyarakat

D. Bidang Kesehatan

1) Kurangnya sosialisasi tentang perilaku hidup bersih dan sehat

2) Kurangnya kesadara para pemuda/i untuk mengadakan olahraga secara rutin.

4. Tahap Penyusunan Program

Pada tahap ini, dari rumusan masalah yang telah dimasukkan ke masingmasing bidang kerja mulailah disusun program-program yang relevan sebagai solusidari berbagai masalah yang ditemukan pada saat observasi. Program ini disusun dengan memperhatikan berbagai hal seperti manfaatkan program bagi warga masyarakat Kampung Cihideung Udiksehingga 


\section{IMPLEMENTASI HASIL KEGIATAN}

Sesuai dengan ketentuan dan jadwal yang telah ditetapkan oleh LPPM (Lembaga Penelitian dan Pengabdian Masyarakat) Universitas Ibn Khaldun Bogor adalah 30 hari yang di mulai dari tanggal 7 Agustus 2018 sampai 07 September 2018, yang bertempat di Kampung Cihideung Pojok Desa Cihideung Udik Kecamatan Ciampea.

Adapun pembagian kelompok terdiri dari enam fakultas dan berbagai jurusan yang berjumlah 13 orang, kami bagi ke dalam beberapa divisi dan juga koordinator sebagai berikut: 1) Koordinator KKN Desa Cihideung Udik 2) Sekretaris, 3) Bendahara, 4) Divisi Pendidikan, 5) Divisi Kesehatan, 6) Divisi Lingkungan. Susunan Organigram Kelompok KKN 18 Desa Cihideung Udik adalah sebagai berikut :

\section{Bidang Pendidikan}

- Mengajar di SDN 03 Cihideung Udik

- Mengajar di Majlis Taklim

- Melakukan Kegiatan Bimbel “ Bahasa Inggris“

- Melakukan kegiatan mengajar mengaji

- Perlombaan Hari Kemerdekaan 17 Agustus

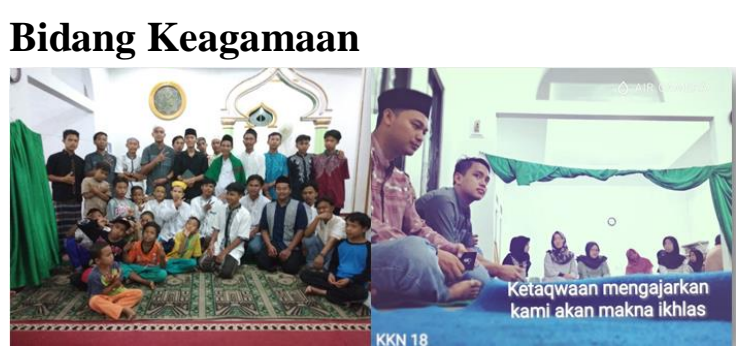

- Ikut Serta dalam Pengajian Mingguan para pemuda

- Ikut Serta dalam pengajian mingguan Ibu-ibu

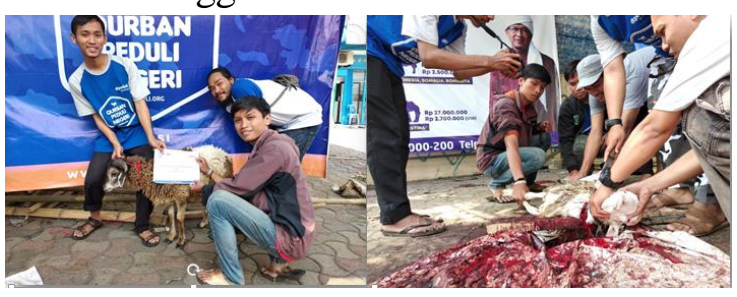

- Mengadakan penyaluran hewan kurban dari Dt Peduli, Bogor ke lokasi KKN kampung Cihideung Udik

- Mengadakan penyaluran Al-quran ke beberapa majlis taklim yang ada di kp. Cihideung pojok

Bidang Kesehatan Dan Lingkungan

- Kegiatan Bersih Bersih Lingkungan

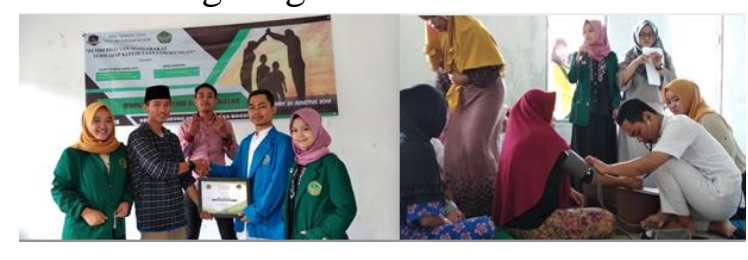

- Melakukan Kegiatan Penyuluhan kesehatan

- Melakukan kegiatan penyediaan Tong sampah 


\section{KESIMPULAN}

Kuliah Kerja Nyata (KKN) yang telah dilaksanakan di Desa Cihideung Udik Kecamatan Ciampea Kampung Cihideung Pojok selama 30 hari sejak tanggal 7 Agustus sampai dengan 07 September 2018, Alhamdulillah mendapat sambutan yang sangat baik.

Dan berkat kerjasama yang solid antar anggota kelompok KKN 18, Dosen Pembimbing Lapangan kami serta bantuan dari masyarakat, hambatan dan kendala yang terjadi, dapat kami atasi dengan baik. Ini dikarenakan kegiatan $\mathrm{KKN}$ adalah kegiatan kelompok, bukan kegiatan individual atau perorangan. Berikut kami sampaikan kegiatan-kegiatan yang kami telah kami jalankan :

\section{Mengajar}

Dilaksanakan dari tanggal 15 Agustus -

23 Agustus 2018 Pukul 07.00 sampai 12.00 di SDN 03 Cihideung Udik. Program ini merupakan program harian dari program kerja KKN Kelompok 18 yang bertujuan untuk memberikan proses pembelajaran yang kontemporer bagi siswa yang didesain semenarik

\section{SARAN}

Sebagai evaluasi dan upaya perbaikan dalam penyelenggaraan program Kuliah Kerja Nyata (KKN) yang akan datang, Baik bagi panitia penyelenggara, peserta, Dewan Pembimbing Lapangan, maupun masyarakat sebagai sasaran KKN, maka kami memberikan saran-saran sebagai berikut :

1. Bagi Peserta Kuliah Kerja Nyata (KKN) Fakultas Agama Islam, Fakultas Ekonomi, Fakultas Keguruan dan Ilmu Pendidikan, Fakultas Teknik, Fakultas Ilmu Kesehatan, dan Fakultas Hukum Universitas Ibn Khaldun Bogor. mungkin agar pembelajaran tidak berlangsung konvensional dan memberikan pengalaman dedikasi bagi mahasiswa khususnya.

2. Menemui Tokoh Masyarakat Dilaksanakan dari tanggal 9 Agustus sampai 13 Agustus pada hari Pukul 09.00 sampai 15.00 dengan mengambil lokasi diDesa Cihideung Udik Kecamatan Ciampea Kampung Cihideung Pojok. Menemui para tokoh masyarakat setempat bertujuan umtuk menjalin silaturahim dan mensosialisasikan program-program KKN.

3. Acara "Perlombaan Kemerdekaan 17 Agustusan"

Dilaksanakan pada hari Jumat, 17 Agustus 2018 di LapanganRT 03 / RW 12. Diikuti oleh Seluruh pemuda, dan seluruh masyarakat, dengan tujuan memperingati hari kemerdekaan RI juga memotivasi masyarakat untuk berlomba-lomba dalam memperjuangkan kemerdekaan.

a. Lebih mempersiapkan diri, dalam arti telah siap dengan wawasan, pengetahuan, fisik dan psikologi masyarakat agar dapat membaur dan memahami permasalahan secara tepat dan komprehensif.

b. Lebih mempersiapkan diri mengenai disiplin ilmu yang dimiliki, serta lebih memiliki rasa tanggung jawab dalam melaksanakan tugas.

c. Lebih dapat mengontrol diri, emosi, menjaga lisan dan memperlihatkan akhlakul karimah sebagai mahasiswa muslim selama masa KKN. 
2. Lebih meningkatkan komunikasi yang baik, kerjasama, dan solidaritas antar sesama anggota kelompok KKN, supaya lebih menumbuhkan suasana kekeluargaan, kebersamaan, dan keakraban, mengingat anggota $\mathrm{KKN}$ ini hakikatnya tetap satu naungan Fakultas Agama Islam, Fakultas Ekonomi, Fakultas Keguruan dan Ilmu Pendidikan, Fakultas Teknik, Fakultas Ilmu Kesehatan, dan Fakultas Hukum Universitas Ibn Khaldun Bogor.

3. Bagi DPL

Diharapkan dapat lebih mengontrol amalan ibadah tiap peserta KKN dalam kelompok bimbingannya, agar tidak terjadi kelalaian dalam ibadah. Juga DPL mengontrol dan memperhatikan setiap program yang telah disusun dan direncanakan sehingga program terlaksana dengan baik dan tepat guna.

4. Bagi Panitia LPPM

Hendaknya dalam melaksanakan pembekalan dan pembagian kelompok, ada rentan waktu yang cukup agar tiap

\section{REFERENSI}

http:/id.m.wikipedia.org/wiki/Pemberdaya

an_masyarakat

Proboyekti,umi.2009.Seminar-Bahasa Indonesia:[Online] Tersedia: http://contoh_makalah.doc/127undip.ic.id

Tung, Khoe Yao. 2002. Simphoni Sedih Pendidikan Nasional. Jakarta : Abdi Tandur peserta lebih memiliki persiapan yang matang. Semoga semua saran yang telah dituliskan di atas dapat bermanfaat umtuk semua pihak demi peningkatan kualitas di masa yang akan datang.

5. Bagi Desa

Desa Cihideung Udik tentunya membutuhkan beberapa pilar yang mendukung terlaksananya desa yang maju. Salah satu diantaranya adalah pilar kebersihan. Beberapa temuan yang kami temukan adalah tersedianya sarana kebersihan yang cukup memadai namun tidak diiringi dengan system kebersihan dan kesadaran masyarakat dalam menjaga kebersihan.

Atas segala dukungan, bantuan, serta kepercayaan yang diamanahkan, kami mengucapkan terima kasih yang sebesar-besarnya kepada seluruh pihak terkait. Semoga segala hal yang telah dilakukan bernilai ibadah dan menjadi amal saleh, serta senantiasa diterima dan diridhoi oleh Allah SWT.

Surya, Mohamad. 2004. "Pendidikan Murah, Mungkinkah?” Dalam Pikiran Rakyat 5 Juni. Bandung: PT. Percetakan Offset GRANESIA.

S, D. Sudjana. 2004. Manajemen Program Pendidikan: Untuk Pendidikan Nonformal dan Pengembangan Sumber Daya Manusia. Bandung : Falah Production. 